\title{
EFEKTIVITAS PENGENDALIAN HAMA TIKUS PADA TANAMAN PERTANIAN DENGAN PEMANFAATAN BURUNG HANTU DI DESA WRINGINREJO KECAMATAN GAMBIRAN KABUPATEN BANYUWANGI, PROVINSI JAWA TIMUR
}

\author{
Made Dwi Pusparini ${ }^{1}$, I KetutSuratha ${ }^{2 *}$
}

Prodi Pendidikan Geografi, Jurusan Geoografi, Universitas Pendidikan Ganesha, Indonesia

\section{A R T I C L EI N F O}

Article history:

Received 19 April 2018

Received in revised form

6 Agustus 2018

Accepted 12 Agustus 2018

Available online 31 Agustus 2018

Kata Kunci:

Efektivitas, Pengendalian,

Tanaman Pertanian,

Pemanfaatan Burung

Hantu.

Keywords:

effectiveness, control,

agricultural crops, barn owl

utilization meter, (2) Kendala kurangnya informasi tentang manfaat burung hantu untuk mengendalikan hama tikus, keterbatasan modal pemanfaatan Burung Hantu. Kelemahan dari pemanfaatan burung hantu adalah ilmu dalam merawat burung hantu yang harus dipelajari,(3) Berdasarkan hasil Uji T Sampel Bebas, pemanfaatan burung hantu berdampak pada peningkatan semua komoditas pertanian di Desa Wringinrejo.

\section{A B S T R A C T}

This research was conducted in Wringinrejo village, Gambiran sub-district, Banyuwangi regency and aimed at: (1) describing the mechanism of using owls effort to control rodents in agricultural crops, (2) describing obstacles encountered in utilizing owls pest control method, and (3) describing effectiveness of owl effort to control rodents in agricultural crops. This research is descriptive research with quantitative data analysis. This research did used key informant technique. The data was collected using interview and observation techniques, analyzed descriptive and T-Test Sample. Will showed that (1) Take the advantages that owls able to hear sound of rats from distance of 500 meters, (2) lack of information about the benefits of owls to control rodents, Capital limitations use owls. The weakness of using owls is that owlcaring knowledge must be thoroughly studied, (3) based on the results of Independent sample T-test, Used of owls has impact on increasing agricultural commodities in Wringinrejo Village.

\footnotetext{
* Corresponding author.

E-mail addresses:penulis1@undiksha.ac.id (PenulisPertama), penulis2@undiksha.ac.id (PenulisKedua)
} 


\section{Pendahuluan}

Definisi geografi pertanian dapat dinyatakan sebagai bagian studi geografi yang mempelajari persamaan dan perbedaan fenomena pertanian di permukaan bumi dengan menggunakan hampiran ekologi dan regional dalam konteks keruangan. Berdasarkan definisi ini, geografi pertanian memusatkan perhatian pada pengenalan, pendekskripsian dan analisis variasi spasial fenomena pertanian di berbagai permukaan bumi, dan selanjutnya menjelaskan mengapa terjadi variasi spasial tersebut dengan menggunakan hampiran atau pendekatan ekologi dan kewilayahan (Sriartha,2000).

Sektor pertanian merupakan salah satu sektor yang selama ini masih diandalkan oleh Negara Indonesia karena sektor pertanian mampu memberikan pemulihan dalam mengatasi krisis yang terjadi di Indonesia. Keadaan inilah yang menampakkan bahwa sektor pertanian sebagai salah satu sektor yang andal dan mempunyai potensi besar untuk berperan sebagai pemicu pemulihan ekonomi nasional melalui salah satunnya adalah ketahanan pangan nasional. Bagi Indonesia, masalah ketahanan pangan sangatlah krusial. Pangan merupakan basic human need yang tidak ada substitusinya. (Suratha,2014).

Keberadaan dan ketersediaan lahan sawah memiliki peran strategis bagi Indonesia yang mayoritas makanan pokok penduduknya adalah beras. Di samping sebagai sumber produksi pangan untuk mewujudkan kemandirian, ketahanan, dan kedaulatan pangan nasional secara berkelanjutan, lahan sawah juga memiliki peran positif yang beragam dalam mendukung pembangunan berkelanjutan (Sriartha dkk, 2015). Kebijakan pembangunan pertanian jangka menengah (2015-2016) pemerintah mencanangkan berbagai macam kebijakan diantaranya adalah peningkatan ketersediaan pangan melalui penguatan kapasitas produksi padi, peningkatan aksesibilitas masyarakat terhadap pangan, meningkatkan perbaikan kualitas konsumsi pangan dan gizimasyarakat, dan mitigasi gangguan terhadap kedaulatan pangan yang bertujuan untuk dapat meningkatkan produksi padi, jagung dan produksi ikan Pembangunan pertanian berperan strategis dalam perekonomioan nasional. Peran strategis tersebut ditunjukkan oleh perannya dalam pembentukan kapital, penyediaan bahan pangan, bahan baku industri, pakan dan bioenergi, penyerap tenaga kerja, sumber devisa negara, dan sumber pendapatan, serta pelestarian lingkungan melalui praktek usaha tani yang ramah lingkungan. Pembangunan pertanian di Indonesia diarahkan menuju pembangunan pertanian yang berkelanjutan (sustainable agriculture), sebagai bagian dari implementasi pembangunan berkelanjutan (sustainable development). Pembangunan pertanian (termasuk pembangunan perdesaan) yang berkelanjutan merupakan isu penting strategis yang menjadi perhatian dan pembicaraan disemua negara dewasa ini. Pembangunan pertanian berkelanjutan selain sudah menjadi tujuan, tetapi juga sudah menjadi paradigma pola pembangunan pertanian (Rival dkk, 2011)

Pertanian sekarang ini mengalami berbagai macam permasalahan terutama dengan adanya revolusi hijau (green revolution) dimana lebih mengedepankan pada pemanfaatan teknologi modern yang dampaknya sangat serius terutama penggunaan obat-obatan dan pupuk kimiawi.Permasalahan-permasalahan yang dihadapi petani yang diantaranya adalah menurunnya kualitas kesuburan tanah, banyaknya hama dan penyakit tanaman, dan perubahan iklim yang tidak menentu (Banyuwangikab, 2017). Penurunan produktivitas pertanian yang terjadi hampir di seluruh kecamatan yang ada di Kabupaten Banyuwangi, salah satunya di Kecamatan Gambiran. Penurunan produktivitas pertanian disebabkan oleh adanya serangan hama salah satunya adalah hama tikus. Untuk lebih jelasnya perhatikan tabel 1 berikut.

Tabel 1 Komulatif Luas Tambah Serangan OrganismePengganggu Tanaman Padi Musiman Kecamatan Gambiran

\begin{tabular}{|c|c|c|c|c|}
\hline No & OPT & $\begin{array}{c}\text { MP Akhir } \\
\text { tahun } 2014 \\
\text { (ha) }\end{array}$ & $\begin{array}{l}\text { MP Awal tahun } \\
2015 \\
\text { (ha) }\end{array}$ & $\begin{array}{l}\text { MP Akhir tahun } \\
2015 / \\
\text { (ha) }\end{array}$ \\
\hline 1 & $\begin{array}{l}\text { Xanthomonas } \\
\text { oryzae }\end{array}$ & 8,75 & 7,50 & \\
\hline
\end{tabular}




$\begin{array}{lllll}2 & \text { Tikus } & 0,25 & 0,75 & 0,25 \\ 3 & \text { Wereng Coklat } & 0 & 0,50 & 0 \\ 4 & \text { Penggerek } & 1,75 & 4,50 & 4 \\ & \text { Batang } & & 26 & 5,25 \\ 5 & \text { Pyricularia Oryzae } & 8,25 & 26 & \end{array}$

Sumber: Pengamat Organisme Pengganggu Tanaman di Desa Wringinrejo Kecamatan Gambiran Kabupaten Banyuwangi , Tahun 2014/2015

Keterangan:MP= Musim Penghujan

Dari tabel 1.1 Komulatif Luas Tambah Serangan Organisme Pengganggu Tanaman Padi Musiman Kecamatan Gambirandiatas terlihat bahwa serangan hama tikus terhadap lahan pertanian mengalami fluktusi dari akhir tahun 2014 sampai tahun 2015 akhir. Walaupun demikian hama jenis ini agak sulit diberantas padahal di tahun-tahun sebelumnya sudah menggunakan berbagai macam metode untuk memusnahkan tikus.

Tikus selalu menimbulkan kerusakan tanaman pertanian di lapangan dan produk pertanian yang ada di gudang penyimpanan. Kerusakan yang diakibatkan oleh tikus bervariasi tergantung dari stadium tanaman yang dirusaknya, hal tersebut dipengaruhi oleh tinggi rendahnya populasi tikus yang ada di persawahan (Agustini, 2013).Sudah banyak petani tanaman pangan yang kehilangan hasilnya secara menyeluruh (fuso) hanya dalam waktu 1 malam dari seluruh areal pertanaman yang ada. Tikus menggasaktanaman pangan sehingga rata dengan tanah (Sudarmaji dkk, 2009).

Metode yang sudah digunakan dalam memberantas hama tikus di desa Wringinrejo berupa gropyoan,pengasapan,umpan beracun, pemasangan bambu perangkap, sanitasi lingkungan dan penggenangan. Startegi tersebut hanya efektif pada saat itu saja dan Masyarakat di Desa Wringnrejo, saat ini mulai tertarik untuk memanfaatakan musuh alami sebagai pengendali hama tikus yaitu burung hantu (tyto alba). Burung hantu tikus tetap kembali merusak tanaman pertanian dikarenakan perkembangan populasi hama tikus yang cepat. Hal ini membuat petani harus menelan kerugian yang cukup besar dengan turunnya hasil produksi pertanian. Jika hal ini tidak cepat ditanggulangi, akibatnya akan terjadi krisis pangan yang dapat merugikan masyarakat.

Tikus salah adalah satu makanan spesifik burung hantu. Burung hantu dewasa dapat memangsa tikus sebanyak $2-5$ ekor tikus setiap harinya. Jika tikus sulit didapat, tak jarang burung ini menjelajah kawasan berburunya hingga $12 \mathrm{~km}$ dari sarangnya (Agustini,2013). Kerusakan yang diakibatkan hama tikus cukup luas dan hampir terjadi setiap musim.

Pengendalian tikus bukan hal yang mudah karena tikus menempati habitat yang sesuai dan keperidiannya tinggi. Analisis spesies tikus yang menjadi masalah di pertanian pada berbagai bagian dunia memperlihatkan keragaman yang nyata dari sudut ekologi. Ini berarti bahwa pengelolaan setiap spesies tikus untuk setiap lokasi spesifik harus dirancang secara khusus pula. Pengendalian dengan satu metode seperti pengendalian keperidian, penggunaan predator, mengurangi pemencaran atau kombinasi cara-cara tersebut mungkin efektif untuk satu spesies, tetapi tidak untuk spesies yang lain $(B a c 0,2011)$ dapat dipelihara dan dimanfaatakan sebagai musuh alam karena burung hantu memangsa bermacam-macam jenis serangga maupun tikus yang merusak tanaman pertanian (Sutanto 2002:194). Penanganan dengan memanfaatkan predator ini dirasa cukup efektif, efisien dan tidak memiliki dampak lingkungan terhadap lahan pertanian, hasil pertanian dan dampak kesehatan terhadap petani (Setiabudi, 2015).

\section{Metode}

Penelitian ini dilakukan di Desa Wringinrejo, KecamatanGambiran, Kabupaten Banyuwangi. Objek dalam penelitian ini adalah Keadaan Pertanian di Desa Wringinrejo, Penangkaran Burung Hantu, dan Efektifitas Penggunaan Burung Hantu. Subjek dalam penelitian ini yaitu petani yang menggunakan burung hantu Tyto Alba dan yang tidak menggunakan burung hantu Tyto Alba dalam kegiatan pertanian. Populasi dalam penelitian 
ini adalah seluruh kelompok tani di Desa Wringinrejo yaitu 9 kelompok tani. Penelitian ini menggunakan rancangan penelitian deskriptif dengan analisis kuantitatif. Pendekatan yang digunakan dalam penelitian iniadalah pendekatan kelingkungan. Data Primer diperoleh langsung melalui observasi, wawancara sedangkan data sekunder diperoleh melalui observasi lapangan, pencatatan, studi pustaka, dokumentasi.Data primer yang telah dikumpulkan selanjutnya akan dianalisis menggunakan analisis Kualitatif sedangkan data sekunder akan dianalisis dengan analisis kuantitatif Uji T Dua Sampel. Terkait dengan pemanfaatan burung hantu menggunakan pendekatan kelingkungan. Terkait dengan kendala pemanfaatan burung hantu menggunakan pendekatan kelingkungan.

\section{Hasil dan pembahasan}

\section{Pemanfaatan Burung Hantu di Desa Wringinrejo}

Tim karantina burung hantu (Tyo alba) mengemukakan bahwa pemanfaatan burung hantu di Desa Wringinrejo dimulai pada tahun 2013 kalau dulu biasanya panen bisa menghasilkan kurang lebih 10 karung cabe jadi ternyata hanya mencapai 8 karung pada panen pertama, kemudian pada panen ke 2 dan ke 3 yang semestinya lebih banyak mendapatkan hasil panen ternyata semakin sedikit hingga setengah karung itu ditaruh digudang dengan harapan besok dicari sumber masalahnya setelah ditaruh digudang ternyata tikus semakin banyak sedangkan Menurut Ketua Lintas Lestari seluruh pertanian yang ada di Wringinrejo tidak ada yang berhasil dalam segala bentuk pertanian hingga dari cabe dan jeruk sehingga petani setiap malam berkumpul bersama-sama mencari solusi bagaimana cara untuk mengatasi hama tikus. Setelah itu ada usulan dari penyuluh pertanian untuk mulai memanfaatkan burung hantu sebagai solusi dari masalah pertanian yang dihadapi petani di Desa Wringinrejo.

Penyuluh pertania dan petani berangkat ke Demak untuk belajar memafaatkan burung hantu kemudian diterapkan di Desa Wringinrejo. Masalah-masalah yang timbul dalam pemanfaatan burung hantu ini adalah masalah dari pemikiran petani bahwa racun masih efektif dalam memusnahkan hama tikus. Pembuatan rubuha atau pagupon sebagai tempat tinggal burung hantu dikerjakan secara gotong royong masyarakat Desa Wringinrejo dengan biaya pembuatan yang berasal dari swadaya petani.

Pemanfaatan burung hantu adalah rekomendasi pembuatan Peraturan Desa (Perdes) khusus perlindungan burung hantu dan pemanfaatannya. Pembentukan perdes ini sangat diperlukan mengingat burung hantu saat ini sudah menjadi asset yang sangat bernilai sehingga keberadaannya harus dilindungi dan dilestarikan (Setiabudi,2015). Didalam melaksanakan pemanfaatan burung hantu tersebut desa Wringinrejo memiliki peraturan desa yang berguna untuk melindungi keberadaan burung hantu dari pemburu-pemburu liar yaitu Perdes Nomer 3 Tahun 2013.

\section{Kendala yang dihadapi oleh Pengelola dan Petani dalam Pemanfaatan Burung Hantu di Desa Wringinrejo, Kecamatan Gambiran Kabupaten Banyuwangi}

Kendala yang dihadapi oleh pengelola dan Petani dalam pemanfaatan burung hantu yang dikembangkan di Desa Wringinrejo adalah sebagai berikut:

1. Kendala Pengelola dalam Pemanfaatan Burung Hantu

Desa Wringinrejo yang dikenal sebagai kawasan pertanian memiliki masalah pada pertanian yaitu hama tikus. Petani mulai mencari alternatif lain untuk memusnahkan hama tikus yang sangat mengganggu lahan pertanian yaitu menggunakan burung hantu Tyto Alba. Burung hantu merupakan salah satu alternatif untuk mengendalikan hama tikus di areal persawahan maupun perkebunan namun tidak semua petani melaksanakannya karena masih adanya mitos memelihara burung hantu membuat sial dan burung hantu sudah terlanjur memiliki nama yang jelek "hantu" tersebut juga masih adanya orang iseng untuk membunuhnya. Ketidaksabaran petani terhadap hasil dari pemanfaatan burung hantu menyebabkan masih banyak masyarakat yang menggunakan racun tikus untuk membunuh 
hama tikus. Minimnya informasi tentang manfaat burung hantu untuk mengendalikan hama tikus menyebabkan masyarakat tidak secara langsung dapat menerima teknologi baru.

Burung hantu banyak dikaitkan dengan berbagai mitos yang menyeramkan, burung ini selalu dekat dengan hantu sehingga suaranya jadi pertanda keberadaan hantu. Burung hantu hidup pada malam hari, karena pada siang hari mata dari burung ini tidak dapat melihat secara jelas. Dampak negatif dari keberadaan mitos burung hantu ini mengakibatkan ketakutan yang dialami oleh masyarakat, keresahan-keresahan akan adanya burung hantu.

2. Kendala Petani dalam Pemanfaatan Burung Hantu

Para petani yang memanfaatakan burung hantu memiliki keterbatasan modal dalam memanfaatkan burung hantu, menyebabkan pagupon atau rubuha yang digunakan untuk burung hantu juga masih sederhana dan bersifat tradisional akibatnya pagupon tidak dapat bertahan lama dan sering kali rusak. Hal ini menyebabkan burung hantu merasa tidak nyaman.

Perilaku petani juga berperan penting terhadap penanggulangan hama tikus sawah karena terkait dengan partisipasi petani. Semakin aktif petani maka akan semakin menunjang keberhasilan kegiatan penanggulangan tersebut, begitu juga sebaliknya, ketidakaktifan petani akan menghambat proses penanggulangan hama tikus sawah tersebut. Kendala utama pada saat pagupon atau rubuha non permanen rusak atau jatuh petani tidak langsung mencoba untuk mendirikan dan hanya menunggu pihak pengelola yang datang untuk memperbaiki.

Kelemahan dari pemanfaatan burung hantu adalah ilmu dalam merawat burung hantu yang harus benar-benar dipelajari.Burung hantu perlu penanganan cepat baik itu perawatannya maupun penanganan saat sakit, menjaga agar burung hantu tersebut tidak menganggap diri kita bukan mangsanya karena burung hantu mudah stress sehingga penanganannya harus dilakukan oleh petugas yang memiliki pengetahuan yang cukup tentang sifat burung hantu.

\section{Efektivitas Pemanfaatan Burung Hantu Sebagai Pengendali Hama Tikus}

Berkembangnya pemanfaatan burung hantu sebagai pengendali hama tikus memberikan kontribusi yang signifikan terhadap produktivitas pertanian di Desa Wringinrejo, berbeda halnya dengan sistem pertanian yang tidak memanfaatkan burung hantu dimana memberikan kontribusi yang sedikit terhadap produktivitas pertanian, dapat dilihat pada Tabel 2.

Tabel 2. Produktivitas Pertanian Menggunakan Burung Hantu dan Tidak Menggunakan Burung Hantu Desa Wringinrejo Tahun 2016

\begin{tabular}{cccc}
\hline No & Komoditas & \multicolumn{2}{c}{ Produktivitas Pertanian Tahun 2016 } \\
\cline { 3 - 4 } & & $\begin{array}{c}\text { Memanfaatan burung hantu } \\
\text { (Kwintal/Ha) }\end{array}$ & $\begin{array}{c}\text { Tidak Memanfaatan Burung } \\
\text { Hantu (Kwintal/Ha) }\end{array}$ \\
\hline 1 & Padi & 43 & 16 \\
2 & Jagung & 35 & 15 \\
3 & Kedelai & 10 & 10 \\
4 & Kacang Tanah & 15 & 5 \\
5 & Kacang Hijau & 10 & 10 \\
6 & Ubi kayu & 20 & 5 \\
\hline 7 & Ubi jalar & 22 & 10 \\
\hline & Total & $\mathbf{1 1 5}$ & $\mathbf{7 1}$ \\
\hline & Rata-rata & $\mathbf{1 6}$ & $\mathbf{1 0}$
\end{tabular}

Sumber: Data Pertanian Desa Wringinrejo,2017

Berdasarkan tabel produktivitas pertanian menggunakan Burung Hantu dan Tidak Menggunakan Burung Hantu Desa Wringinrejo. Pada produktivitas pemanfaatan burung 
hantu komoditi tertinggi terdapat pada komoditi padi dengan jumlah $43 \mathrm{kwintal} / \mathrm{ha}$ dan komoditi terendah terdapat pada komoditi kedelai dan kacang hijau dengan jumlah 10 kwintal/ha serta rata-rata dari produktivitas pemanfaatan burung hantu adalah $16 \mathrm{kwintal} / \mathrm{ha}$. Produktivitas pertanian tidak menggunakan burung hantu komoditi tertinggi terdapat pada komoditi padi dengan jumlah $16 \mathrm{kwintal} / \mathrm{ha}$ dan komoditi terendah terdapat pada komoditi kacang tanah dan ubi kayu dengan jumlah $5 \mathrm{kwintal} / \mathrm{ha}$ serta rata-rata dari produktivitas tidak menggunakan pemanfaatan burung hantu adalah $10 \mathrm{kwintal} / \mathrm{ha}$.

Tabel 3. Uji T Sampel Bebas Independent Samples Test

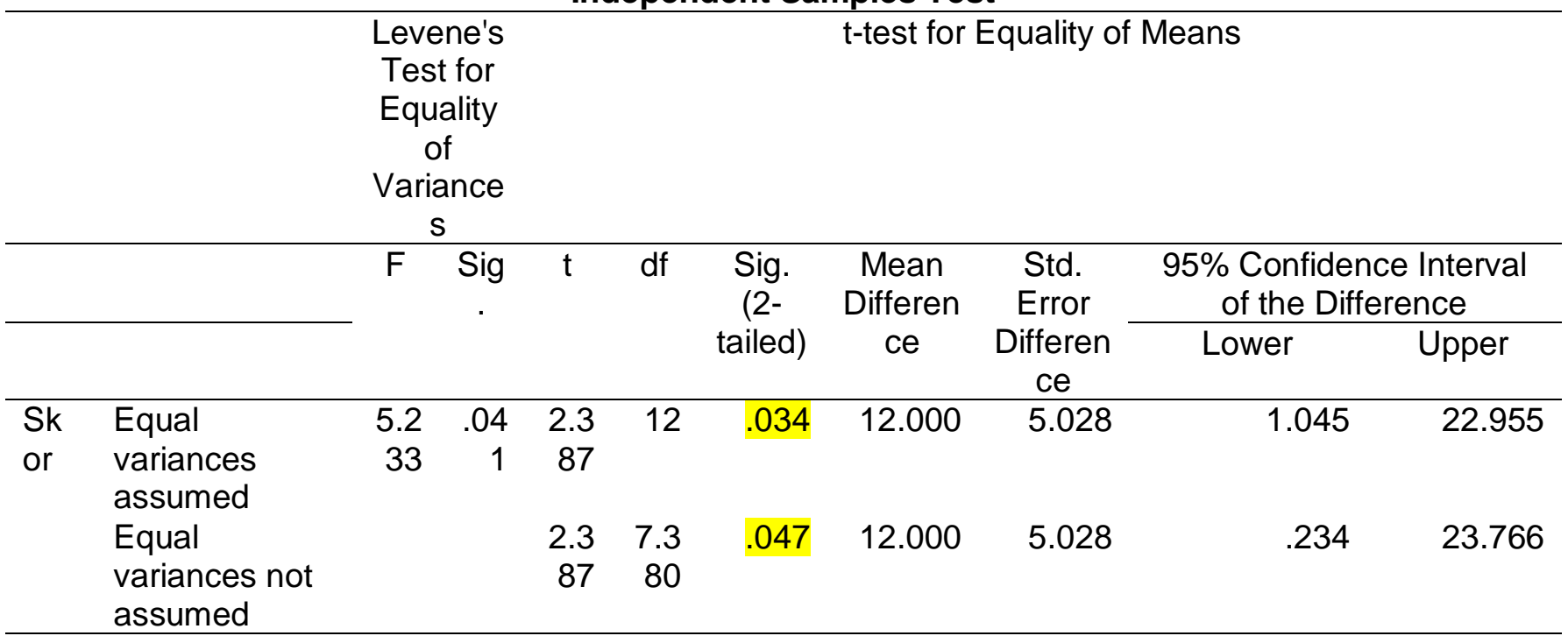

Karena sig $<0,05$ maka Ho ditolak, jadi pemanfaatan burung hantu di desa Wringinrejo efektif jika dibandingkan dengan yang tidak menggunakan pemanfaatan burung Hantu dilihat dari produktivitas pertanian.

\section{Pembahasan \\ Pemanfaatan Burung Hantu di Desa Wringinrejo}

Serangan tikus ini mulai dikeluhkan petani Desa Wringinrejodalamlima tahunterakhir yaitu tahun $(2011.2012,2013,2014,2015)$ dengan intensitas yang semakin berat. Tikus biasanya menyerang tanaman padi pada malam hari dan memakan tanaman padi yang dimulai dari tengah lahan padi. Kelompok tani di Desa Wringinrejo, Gambiran Kabupaten Banyuwangi beserta petugas penyuluh lapang, sebenarnya telah melakukan berbagai upaya pengendalian. Teknik pengendalian yang sudah dilakukan petani di Desa Wringinrejo antara lain gropyokan, kegiatan ini melibatkan banyak pihak seperti petani, tentara nasional indonesia (TNI). Hasil dari tindakan pengendalian ini ternyata masih belum menunjukkan hasil yang optimal. Oleh karena itu perlu adanya solusi teknik pengendalian yang ramah lingkungan yaitu pengendalian hayati dengan memanfaatkan musuh alami tikus yaitu Burung Hantu.

Desa Wringinrejo yang memiliki wilayah daratan yang cukup dalam mengembangkan aneka pertanian menyebabkan masyarakat yang tinggal berprofesi sebagai petani. Petani di Desa Wringinrejo memanfaatkan burung hantu sebagai pengendali hama tikus. Untuk menunjang aktivitas pemanfaaatan burung hantu petani secara bergotong royong membangun rubuha (rumah burung hantu) yang digunakan sebagai tempat tinggal yang masih sederhana. Penggunaan bahan yang masih sederhana berpengaruh terhadap kenyaman burung hantu.

Burung jenis Tyto alba merupakan burung predator yang termasuk burung malam mempunyai sifat kanibal dan pembunuh. Burung keluar dari sarangnya pada malam hari mulai matahari terbenam pukul 18.00 wibdan kembali masuk ke sarangnya pada pukul 04.00 wib. Tikus menjadi salah satu makanan spesifik burung hantu, burung hantu dewasa 
bisa memangsa tikus 2 - 5 ekor tikus setiap harinya, jika tikus sulit didapat, burung ini menjelajah kawasan berburunya hingga $12 \mathrm{~km}$ dari sarangnya. Keunggulan Burung Hantu dibandingkan dengan metode pengendalian hama yang lain yaitu memiliki pendengaran sangat tajam dan mampu mendengar suara tikus dari jarak 500 meter, kemampuannya untuk mendeteksi mangsa dari jarak jauh dan kemampuannya menyergap dengan cepat tanpa suara serta sifatnya sebagai hewan nocturnal (mencari makan di malam hari) membuatnya menjadi predator ideal untuk tikus-tikus.

Burung hantu bagi kegiatan pertanian sangatlah berarti.Hal ini mulai dirasakan bagi petani di Desa Wringinrejo.Burung hantu yang ada di Desa Wringinrejo mulai dirasakan memiliki keuntungan baik di bidang pertanian maupun keindahan sehingga dapat meningkatkan pendapatan petani. Kelebihan lain pemanfaatan burung hantu yaitu aktif pada malam hari dengan penglihatan yang sangat tajam dan dapat melihat mangsa pada jarak yang jauh, hal ini sesuai dengan aktivitas tikus yang juga aktif malam hari.

Penelitian sejenis mengenai pemanfaatan burung hantu juga pernah dilakukan oleh Hasiholan (2014) dengan hasil Pengembangan burung hantu di perkebunan Pt. SIMP \& subs (Pt. Salim Ivomas Primer dan anak perusahaan) dengan metode pena dan pena metode pena telah berkembang secara eksponensial pada bulan April 2002 telah menghasilkan sebanyak 14.310 bibit pohon. Berarti pemasangan sarang burung memastikan burung hantu sangat efektif mengendalikan hama tanaman untuk menghasilkan tikus (TM), terutama jika dilakukan secara konsisten dan 100\% (tidak dikombinasikan dengan racun tikus).

\section{Kendala Pemanfaatan Burung Hantu di Desa Wringinrejo}

Keterbatasan modal yang dimiliki oleh petani di Desa Wringinrejo, menyebabkan bahan yang digunakan dalam membuat rubuha atau pagupon masih sederhana akibatnya rubuha atau pagupon cepat rusak dan roboh karena bahan yang digunakan dari kayu sehingga mudah burung pelatuk merusak tiang dari rumah burung hantu.

Kondisi rubuha atau pagupon juga perlu mendapat perhatian yang serius. Burung hantu merupakan burung hantu yang butuh kenyamanan, juga harus mempunyai tempat tinggal yang nyaman dengan tidak adanya suara yang dapat mengganggu ketenangan burung hantu seperti suara senapan, maka dari itu pemerintah mengeluarkan peraturan desa sebagai langkah untuk melindungi keberadaan burung hantu dari aktivitas manusia yang dapat mengurangi populasi burung hantu.

Dengan adanya pemahaman masyarakat yang kurang mengenai burung hantu menyebabkan masyarakat yang tinggal dekat dengan pagupon atau rubuha menjadi takut dikarenakan adanya mitos yang kurang baik mengenai keberadaan burung hantu masyarakat percaya bila ada burung hantu maka ada tetangga sekitar yang meninggal dunia.

Teknologi pemanfaatan burung hantu ini tidak bisa secara cepat dimengerti oleh petani. Petani secara bertahap harus dikenalkan bagaimana cara kerja burung hantu karena banyak petani yang masih kurang percaya cara kerja burung hantu dalam mengatasi masalah pertanian, mereka berfikiran tidak mungkin burung hantu bisa mengatasi burung hantu dan hasilnya sama saja dengan metode-metode yang digunakan sebelumnya dalam mengatasi hama tikus. Ketidaksabaran petani terhadap hasil dari pemanfaatan burung hantu menyebabkan masih banyak masyarakat yang menggunakan racun tikus untuk membunuh hama tikus.

Kelemahan dari pemanfaatan burung hantu adalah ilmu dalam merawat burung hantu yang harus benar-benar dipelajari.Burung hantu perlu penanganan cepat baik itu perawatannya maupun penanganan saat sakit, menjaga agar burung hantu tersebut tidak menganggap diri kita bukan mangsanya karena burung hantu mudah stress sehingga penanganannya harus dilakukan oleh petugas yang memiliki pengetahuan yang cukup tentang sifat burung hantu.

Hasil penelitian Salaki (2007) menunjukkan bahwa terdapat tiga spesies cendawan patogen pada tanaman sayuran di Kecamatan Tomohon dan Modoinding. Cendawan patogen yang menginfeksi larva-larva serangga hama tanaman sayuran adalah Nomuraea 
sp, Metarhzium sp., dan Hirssutella sp (Sembel et al., 2007). Cendawan-cendawan patogen banyak ditemukan pada tanaman sayuran di Rurukan dan Paslaten, Kota Tomohon. Apabila epizootic tinggi, infeksi cendawan patogen pada larva-larva tanaman sayuran akan terjadi. Cendawan-cendawan patogen tersebut belum dimanfaatkan oleh petani karena mungkin mereka belum mengetahui peranan cendawan terhadap serangga hama sayuran dan cara mengaplikasikannya. Terkait hal tersebut, informasi tentang cendawan patogen dan peranannya perlu diperkenalkan kepada petani sayuran di Kabupaten Minahasa Selatan agar mereka dapat memanfaatkan cendawan entomopatogen untuk digunakan sebagai agen pengendali serangga hama pada tanaman sayuran. Akan tetapi, aplikasi cendawan patogen tidaklah semudah aplikasi insektisida sintetik di lapangan. Penyemprotan insektisida sintetik dapat dilakukan di sebarang waktu asalkan tidak turun hujan. Hal itu berbeda dengan penyemprotan bioinsektisida atau cendawan patogen yang memerlukan waktu khusus agar penyemprotan menjadi efektif untuk menekan populasi hama tanaman sayuran. Kebutuhan cendawan patogen yang dapat diaplikasikan pada serangga hama tanaman sayuran perlu diinformasikan kepada petani agar penggunaan jamur patogen menjadi efektif untuk menekan populasi serangga hama tanaman sayuran.

\section{Efektivitas Pemanfaatan Burung Hantu Sebagai Pengendali Hama Tikus di Desa Wringinrejo Kecamatan Gambiran Kabupaten Banyuwangi}

Pemanfaatan burung hantu memberikan kontribusi yang tinggi terhadap petani di Desa Wringinrejo khusunya pada produktivitas pertanian mengakibatkan terjadinya efektivitas dari pemanfaatan burung hantu di Desa Wringinrejo. Adapun Kelompok tani yang menggunakan pemanfaatan burung hantu, yakni kelompok tani brantas, semeru, tani taruna, bengawan, asahan dan pelita sedangkan kelompok tani yang tidak menggunakan pemanfaatan burung hantu, yakni kelompok tani citarum, rojolele dan serang.

Kelompok tani yang menggunakan pemanfaatan burung hantu produktivitasnya lebih tinggi dibandingkan dengan kelompok yang tidak menggunakan pemanfaatan burung hantu pada sistem pertanian dikarenakan cara kerja burung hantu dalam mengendalikan hama tikus di Desa Wringinrejo sangat baik serta dari adanya pemanfaatan burung hantu sangat membantu para petani membasmi hama salah satunya hama tikus.

Hasil penelitian ini berbeda dengan temuan Ir. Bukti Hasiholan Rajagukguk yang meneliti tentang pemanfaatan burung hantu (Tyto Alba) untuk pengendalian hama tikus di perkebunan kelapa sawit, mengemukakan Burung hantu terbukti efektif mengendalikan hama tikus secara berkesinambungan dibawah ambang ekonomis (kerusakan buah digigit tikus $<5 \%$, Biaya pengendalian hama tikus per hektar menggunakan burung hantu hanya $15,7 \%$ dibanding racun tikus (karat) atau biaya yang dihemat sebesar Rp. 25.473,- per ha, disamping efeknya ramah lingkungan.

Setiabudi (2015) dalam penelitian " Analisis Prioritas Kebijakan Pemanfaatan Burung Hantu (Tyto Alba) Sebagai Pengendali Hama Tikus Sawah Yang Ramah Lingkungan Di Kabupaten Semarang" menemukanprioritas yang dapat diambil adalah Pertama, karantina burung hantu dapat dilakukan di masa mendatang karena memiliki sumberdaya berupa burung hantu yang telah berkembang. Saat ini di Kabupaten Semarang belum memiliki karantina burung hantu. Karantina burung hantu memang tidak mutlak diperlukan dalam penanganan hama tikus sawah, namun dalam pengembangannya mendatang akan dapat memberikan nilai tambah yang lebih bermanfaat. Pengembangan predator burung hantu melalui karantina bisa menjadi prioritas ke depan di Kabupaten Semarang atau di Kecamatan Banyubiru khususnya karena memiliki banyak manfaat antara lain ekonomi, lingkungan dan sosial. Secara ekonomi burung yang dikarantina dapat dijual sehingga mendatangkan keuntungan. Kedua, Prioritas kedua dalam pengembangan pemanfaatan burung hantu adalah rekomendasi pembuatan Peraturan Desa (Perdes) khusus perlindungan burung hantu dan pemanfaatannya. Ketiga, Pembuatan rumah burung hantu (rubuha) juga bermanfaat sebagai sarana pengembangbikan burung hantu secara alami.

\section{Simpulan dan saran}


Berdasarkan pembahasan di atas, maka simpulan yang dapat ditarik diantaranya: Potensi Pertanian di Desa Wringinrejo beranekaragam diantaranya sayuran, buah-buahan dengan adanya potensi tersebut maka, dapat timbul perusak keindahan potensi pertanian di desa Wringinrejo yaitu tikus. Serangan tikus ini mulai dikeluhkan petani Desa Wringinrejodalamlima tahun terakhir. Petani kemudian memanfaatkan musuh alami tikus yaitu Burung Hantu. Keunggulan Burung Hantu dibandingkan dengan metode pengendalian hama yang lain yaitu memiliki pendengaran sangat tajam dan mampu mendengar suara tikus dari jarak 500 meter, kemampuannya untuk mendeteksi mangsa dari jarak jauh dan kemampuannya menyergap dengan cepat tanpa suara serta sifatnya sebagai hewan nocturnal (mencari makan di malam hari) membuatnya menjadi predator ideal untuk tikus.Kendala dalam pemanfaatan burung hantu di Desa Wringinrejo diantaranya kepercayaan petani terhadap cara kerja burung hantu, Minimnya informasi tentang manfaat burung hantu untuk mengendalikan hama tikus menyebabkanmasyarakat tidak secara langsung dapat menerima teknologi baru, keterbatasan modal dalam memanfaatkan burung hantu, menyebabkan pagupon atau rubuha yang digunakan untuk burung hantu juga masih sederhana dan bersifat tradisional akibatnya pagupon tidak dapat bertahan lama dan sering kali rusak. Teknologi pemanfaatan burung hantu ini tidak bisa secara cepat dimengerti oleh petani. Petani secara bertahap harus dikenalkan bagaimana cara kerja burung hantu, karena banyak petani yang masih kurang percaya cara kerja burung hantu dalam mengatasi masalah pertanian. Kelemahan dari pemanfaatan burung hantu adalah ilmu dalam merawat burung hantu yang harus benar-benar dipelajari. Berdasarkan hasil Uji T Sampel, efektivitas pemanfaatan burung hantu tinggi terhadap semua komoditas pertanian di Desa Wringinrejo hal ini dikarenakan pemanfaata burung hantu memberikan konstribusi yang tinggi pula terhadap pembasmian hama tikus pada lahan pertanian di Desa Wringinrejo.Saran yang disampaikan oleh peneliti yaitu (1) Bagi masyarakat khususnya petani diharapkan untuk terus melestarikan keberadaan burung hantu. (2) Pemerintah sebaiknya ikut serta dalam mengembangkan pemanfaatan burung hantu di Desa Wringinrejo sebagai upaya untuk keberlanjutan pertanian dan memberikan perhatian lebih terhdap aktivitas pemanfaatan burung hantu di Desa Wringinrejo, Kecamatan Gambiran, Kabupaten Banyuwangi.

\section{Ucapan terimakasih}

Penelitian ini dapat diselesaikan berkat bimbingan dari berbagai pihak. Untuk ini pada kesempatan ini diucapkan terima kasih yang setulus-tulusnya kepada Rektor Universitas Pendidikan Ganesha, Dekan Fakultas Hukum dan IImu Sosial, Ketua Jurusan Pendidikan Geografi, staff dosen dii Jurusan Pendidikan Geografi, Pembimbing Akademik, Pembimbing 1, Pembimbing 2, Penguji 1, dan Penguji 2, Dinas-dinas pemerintahan di Kabupaten Banyuwangi, Kepala Desa Wringinrejo, Kelompok Lintas Lestari Desa Wringinrejo, Penyuluh Pertanian, Dinas Pengairan Kabupaten Banyuwangi, Badan Meteorologi Klimatologi dan Geofisika Kabupaten Banyuwangi, Badan Pusat Statistik Kabupaten Banyuwangi, dan rekan-rekan mahasiswa Jurusan Pendidikan Geografi angkatan 2013.

\section{Daftar Rujukan}

Agustini, Sri.2013. Burung Hantu Pengendali Tikus Secara Hayati. Buletin Ibovasi Teknologi Pertanian.Edisi 1, Vol 1, November 2013. HIm 48-50

Banyuwangi.2017.RPJMD (Rencana Pembangunan Jangka Menengah Daerah).Tersedia pada:http//www.banyuwangikab.go.id/page/perencanaan/rpjmd.html Diakses pada tanggal 31 Maret 2017

Baco, Djafar.2011.Pengendalian Tikus Pada Tanaman Padi Melalui Pendekatan Ekologi.Jurnal Pengembangan Inovasi Pertanian. Vol 4, No (1),HIm 47-62 
Salaki Christina L dan Sherlij Dumalang.2007. Pengendalian Hama Terpadu (PHT) pada Tanaman Sayuran di Kota Tomohon Sulawesi Utara.Indonesian Journal of Community Engagement. Vol. 02, No. 02, Maret 2017,HIm 246-255

Setiabudi Johan, Izzati Munifatul dan Kismartini.2015. Analisis Prioritas Kebijakan Pemanfaatan Burung Hantu (Tyto alba) sebagai Pengendalian Hama Tikus Sawah yang Ramah Lingkungan di Kabupaten Semarang. Jurnal IImu Lingkungan.Vol 04, No 1, HIm. 67-73.

Sriartha, I Putu. 2000. Pengantar Geografi Pertanian. Singaraja: Sekolah Tinggi Keguruan dan Ilmu Pendidikan (Buku Ajar).

Sriartha, I Putu dan Wayan Windia. 2015. Efektivitas Implementasi Kebijkan Pemerintah Daerah dalam Mengendalikan Alih Fungsi Lahan Sawah Subak: Studi Kasus di Kabupaten Badung, Bali. Jurnal Kajian Bali. Volume 05, Nomor 02, Oktober 2015,HIm 327-346.

Statistik Daerah Kecamatan Gambiran 2016. Tersedia pada: https://banyuwangikab.bps.go.id/website/pdf_publikasi/Statistik-Daerah KecamatanGambiran-2016.PDF Diakses pada 26 April 2017

Sutanto, Rahman. 2002. Penerapan Pertanian Organik (Pemasyarakatan dan Pengembangannya). Yogyakarta. Penerbit Kanikius (anggota IKAPI).

Sudarmaji, Herawati N.A. 2009. Ekologi Tikus Sawah dan Teknologi Pengendaliannya. Subang: Balai Besar Penelitian Tanaman Padi (BBPadi).

Suratha, I Ketut. 2014. Dampak Alih Fungsi Lahan Pertanian Terhadap Ketahanan Pangan: Media Komunikasi Geografi.Volume 15 Nomor 2 Desember 2014

Rajagukguk, Bukti Hasiholan. Pemanfaatan Burung Hantu (Tyto Alba) Untuk Pengendalian Hama Tikus di Perkebunan Kelapa Sawit: Jurnal Saintech. Vol 06, Nomor 04, ISBN No.2086-9681

Rival,rudy S dan Iwan S. Anugrah. Konsep dan Implementasi Pembangunan Pertanian Berkelanjutan Di Indonesia: Forum Penelitian Agro ekonomi, Volume 29 No. 1, Juli 2011:13-25 